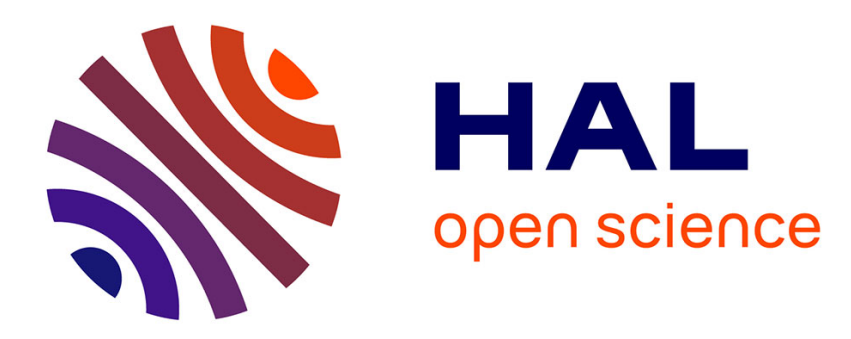

\title{
Mapping Charisma among Chinese Religious specialists
}

Vincent Goossaert

\section{To cite this version:}

Vincent Goossaert. Mapping Charisma among Chinese Religious specialists. Nova Religio, 2008, 12 (2), pp.12-28. halshs-00326356

\section{HAL Id: halshs-00326356 \\ https://shs.hal.science/halshs-00326356}

Submitted on 2 Oct 2008

HAL is a multi-disciplinary open access archive for the deposit and dissemination of scientific research documents, whether they are published or not. The documents may come from teaching and research institutions in France or abroad, or from public or private research centers.
L'archive ouverte pluridisciplinaire HAL, est destinée au dépôt et à la diffusion de documents scientifiques de niveau recherche, publiés ou non, émanant des établissements d'enseignement et de recherche français ou étrangers, des laboratoires publics ou privés. 


\title{
Mapping Charisma among Chinese Religious Specialists
}

\section{Vincent Goossaert}

\begin{abstract}
Modern and contemporary Chinese society, (from 1800 to the present, for the purposes of this article) contains numerous types of religious specialists: Daoists, Buddhists, spirit-mediums, self-cultivation teachers, and so on. Most of these do not construct their authority on a charismatic basis, because the global division of labor in the Chinese religious economy divides leadership and authority among different persons. This article looks at the idioms (emic categories) the Chinese use to describe religious specialists and the division of religious labor. It suggests that situations of charismatic authority arise when one person can overcome the division of labor and be equally convincing in different idioms, thus able to meet all the expectations of the extraordinary from his/her followers. While potential charisma, evident in mastery of the various idioms, is rather common, situations where a charismatic relationship is in fact activated by both leader and followers are less so.
\end{abstract}

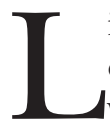

ike my colleagues in this issue, I am interested in exploring how charisma, defined as the "expectation of the extraordinary," can work in modern and contemporary Chinese society, and what the social and religious parameters of such expectations are. More specifically, my larger work on the social history of Chinese religious specialists has led me to encounter, in many texts, and in some field situations, providers of the extraordinary. Only a portion of them however, evolved into a leader-follower relationship that is at the core of any notion of charisma.

For my present purposes, I suggest defining the extraordinary in the Chinese cultural context, that is, in emic terms, as the action of

Nova Religio: The Journal of Alternative and Emergent Religions, Volume 12, Issue 2, pages 12-24, ISSN 1092-6690 (print), 1541-8480 (electronic). (c) 2008 by The Regents of the University of California. All rights reserved. Please direct all requests for permission to photocopy or reproduce article content through the University of California Press's Rights and Permissions website, at http://www.ucpressjournals.com/reprintinfo.asp. DOI: $10.1525 / \mathrm{nr} .2008 .12 .2 .12$ 
someone who moves gods and/or humans to react (ganying) to his/her power. This representation includes successfully entreating the gods to bestow blessings (rain, protection, etc.) and to carry out healing, as well as moving people to achieve or contribute to a daunting task, such as building a very expensive temple, or engaging in a radical re-orientation of their life-style. The power to move others opens new channels of communication, thereby creating new access to transcendent power.

Some religious specialists produce extraordinary happenings from outside any community as experts or resources available on demand: some Buddhists, Daoists, or spirit-mediums can move the gods or humans when invited to. People gain access to them by association e.g., through donations or one-time-only transactions, without entering a leader-follower relationship. So my question is, which among those specialists who provide extraordinary happenings, can be elected or adopted on a long-term basis by a following to be their leader? Under what circumstances? What are the parameters that make stable charismatic authority possible?

Thus phrased, my question remains at the level of ideal types and categories of social actors and social relationships. My concern is to place charisma in the general logic and economy of Chinese religion. I will thus merely evoke some specific examples taken from textual sources as well as field observations. They all deal with modern and contemporary Chinese society, from about 1800 to the present, with a focus on urban society. As I deal with the general logic and economy proper to Chinese religion, I assume basic continuities in what people expect from, and ask of, religious specialists, and I do not deal with historical change here. ${ }^{1}$

I will first sketch a very rough outline of Chinese religious specialists by defining various idioms used to describe and categorize them that are particularly relevant to the issue of charisma. I will then use these categories to explore the relationship between leadership and extraordinariness, both in situations of disjunction (the avoidance of charisma) and conjunction (the search for charisma). I argue that most religious specialists work in a setting where charisma is absent, because a general logic of the division of religious labor makes it difficult to concentrate in a single person all the idioms of religious excellence, a concentration that is strongly linked to charismatic authority.

\section{DESCRIBING RELIGIOUS SPEGIALISTS}

Due to its pluralistic nature, late imperial and modern Chinese religion is characterized by the coexistence of several kinds of religious specialists, providing liturgical and spiritual services to individuals, families and communities. These include Buddhists, Daoists, Confucians-in the sense of clerics, not of "believers"-spirit-mediums, diviners, self-cultivation teachers, and ritual specialists such as musicians. I do not discuss 
Christian and Muslim clerics here because the modes of relationship (charismatic or not) they develop with clients, followers, or believers depend in part on theological and ecclesiastical constructions that were and are imported to China from the outside. Not all of these specialists are susceptible to enter into relationships of charismatic authority. Rather than going through the list to see which type of specialist can build charismatic authority, I find it much more illuminating to look at the idioms used to describe them and see how these idioms and the normative role-models they underline facilitate, or discourage, the construction of charisma.

\section{Providers of the Extraordinary: The Idiom of Self-Cultivation}

One of the words most frequently used to refer to religious specialists in late imperial and modern China is daoren, "man/woman of the Dao." This refers to the sustained practice of self-cultivation, xiudao, which is technically different in each tradition (the various traditions are all called such-and-such dao) but aims at the same goal of transcendence: the unique Dao. Many different kinds of religious specialists, notably Daoists and leaders of lay congregations ( $h u$, groups that organize scripturechanting, pilgrimages, charitable or other activities) used the term daoren in late imperial time. The vocabulary of self-cultivation also contains more specific terms such as the Daoist "True man," zhenren or the Buddhist "Superior man," shangren, but unlike these, the more ecumenical daoren was also used for self-selected surnames. The title is not owned by any institution. Anyone can claim to be a daoren, but only those with proven bodily accomplishments are called such by others.

Two cognate terms are "living Buddha," huofo, and "immortal," xian. Living Buddha is a technical term (tülkü) of Tibeto-mongol Buddhism translated into Chinese, but it is also used to qualify anyone, Buddhist cleric or not, who proves to have achieved total mastery over the physical world. "Immortal" qualifies advanced Daoist practitioners, and is also used to refer to spirit-mediums in reference to the identification of the mediums with the deities possessing them (typically called "immortals") but also to the process of self-cultivation in which they were engaged through contact with deities and services to the population. ${ }^{2}$

Religious specialists who describe themselves, or are described by others, in terms of the self-cultivation idiom cover an extremely wide variety, from meditating scholars to village spirit-mediums, but all share the common point of establishing themselves through bodily practices. As both David Palmer and Ji Zhe illustrate in this issue, regimens of discipline and ascetic prowess, very often staged in a dramatic fashion, ${ }^{3}$ are crucial in establishing one's credentials as a potential charismatic leader. In this regard, miracles play a crucial role. One who has reached the dao or become a Buddha or immortal through mastery over his/her own 
body has by the same token gained mastery, through the process of spontaneous reaction, over the outside world, and can therefore make rain, repel locusts, heal the sick, transform people, and otherwise produce the extraordinary. $\mathrm{S} /$ he is a saint, worshiped, by burning incense when still alive, and, more frequently, after her/his departure from this world. ${ }^{4}$

Indeed, saints are more appreciated when dead, in which state they are more amenable to helping others. The word ling, meaning numinous, efficacious, clever, or spiritual, which is possibly the closest Chinese-language equivalent to "charismatic," is normally used for the dead (one of its meanings is the soul of a deceased person) and rarely for the living-in the same way that incense is normally burned for the dead. For these reasons, the primary candidates for charisma in China would seem to be spirit-mediums, who convey the spiritual power and efficacy of the saints or gods. ${ }^{5}$

\section{Providers of the Necessary: The Idiom of Scholarship and Knowledge}

In contrast to the idiom of self-cultivation that describes individual spiritual qualities, the idiom of scholarship is concerned with technical knowledge acquired through book-learning. The two are not opposed at all, even though there are in China, as anywhere else, ascetics and holy fools on the one hand, and erudite scholars on the other. They may, or may not be, combined in the same person.

The most important term to denote religious specialists credited with expertise and technical knowledge is "master" (lit. first-born), xiansheng. This word, now used in everyday speech for "mister" or "sir" has a long and complicated history. Beginning with texts from late antiquity, it first denoted respect for elders and accomplished scholars. It was appropriated by Daoism as a synonym for "scholar of the dao," daoshi (itself designating Daoists as literate experts). It is still very common today, in many parts of China, to refer to Daoists as xiansheng. The other category of religious specialists widely called xiansheng consists of diviners and geomancers; yet another are the ritual storytellers (xuanjuan xiansheng). The xiansheng category is thus quite inclusive, but it does not include all religious specialists. It refers to those working with books, in contrast to masters in oral traditions (such as spirit-mediums) ${ }^{6}$ It is also used to refer to doctors, bookkeepers, and schoolmasters. Like daoren, xiansheng is very frequently used for self-selected names by intellectuals, but as a term of address, it more frequently refers to religious specialists.

A closely related term is that for Confucian ritual specialists, lisheng (sheng has long been the equivalent of xiansheng), meaning experts in the written liturgical manuals for classical ritual forms. All these terms build on the expression -shi, "scholar or student of" (daoshi, shushi: "scholar of divination techniques") and -sheng. They refer to the fact that, up to the 
middle of the twentieth century, and even now to a certain extent, Daoists, Confucian scholars, and diviners were the major possessors and transmitters of the classical written culture. They were the users of books and providers of services in relation to writing and calligraphy, and wrote letters, prayers, and inscriptions. Such services are not extraordinary in our emic sense, even though one may have extraordinarily beautiful calligraphy; rather, they answer more ordinary needs.

In spite of the differences in the content of their training and professional roles, these various specialists share a common "literary" ethos and lifestyle. They prize privacy, refinement and composure, they hate staging and excessive display, and they do not perform miracles. As my advisor Kristofer Schipper said: "Daoists are not charismatic, because they don't do miracles." The training they receive, based on booklearning and refined self-cultivation techniques-including breathing, meditating, self-introspection-their body techniques-such as composed walking, sitting, and talking styles, in other words their habitusstrongly predispose them against playing charismatic roles. ${ }^{7}$ Some Daoists, Confucians, and Buddhists do play charismatic roles and establish their own following and teaching. More often than not, however, they are rejected, or at least criticized, by fellow clerics, who find them at odds with their class ethos. Daoists themselves have theorized the difference between the two idioms by opposing fashi, masters of dramatic exorcism who work with spirit-mediums and local gods, who are wonderworkers, and daoshi, the performers of the solemn, "pure" classical ritual, who are scholars-although often these are two roles played in turns by a same person. ${ }^{8}$

\section{The Idiom of Discipleship and Genealogy}

How do ordinary people relate to religious specialists working within either one, or a combination of the two above idioms? Strong, durable relationships are described as a genealogical link between the master (shifu, "teacher-father") and the disciple (dizi, "younger brother-son"). In congregations, members consider themselves disciples of the god, sometimes initiated formally through spirit-writing. Many gods are called ancestor-master, zushi. The relationship to a living teacher is conceptualized in a very similar way, and is a social asset. In modern and contemporary Chinese society, it is normal, and even in certain contexts socially required, ${ }^{9}$ to have one or several masters in some body-andmind practice, and let it be known. Even today, businessmen or academics routinely admit in public to being the disciple of such and such respected Buddhist, Daoist, or Confucian master.

Many clerics, notably Daoists, whom I have met in China accept some individuals as their disciples. Within this circle, they enjoy a status we may equate with the charisma of great scholars and scientists. 
However, these clerics primarily work for the clerical institution, rather than building their own following. Their disciples do not normally form a following, as there exists very little in the way of horizontal relationships between them, and they do not learn the same things from the master, and therefore do not have a common practice. Rather, what they value is the individual relationship and the inscription in a lineage. Lineages are very powerful tools for legitimizing practices and gaining social status, but they are not necessarily (and in my experience, not very frequently) based on the charismatic authority of the living master-the charisma often being identified with the past founder of the lineage, the "ancestor-master" (zushi).

\section{The Idiom of Morality and Leadership}

In contrast to self-cultivation or ritual or spiritual knowledge, both of which define individual qualities, the idiom of leadership distinguishes roles within larger religious organizations. (I do not address monastic organization and hierarchy here, but leadership of large social groups.) Terms such as "elder" or "leader" (lit. head), -zhang, -shou are not usually found among religious specialists, but rather among lay people who are nominated as community leaders (huizhang, huishou, xiangtou) often without any religious expertise. They may be temple committee leaders, and typically local elites such as retired officials, rich merchants, or schoolmasters, who may or may not have a sustained interest in things religious, but as a rule do not have any specific training or competence, do not perform rituals on their own, and do not teach.

This seems to refer to a distinction, found throughout modern and contemporary Chinese society, between lay community leaders-chosen by the gods but on the basis of their virtue, as well as financial and other resources-who make decisions (manage the gods' charisma) on the one hand, and religious or ritual experts, who are hired and paid for their participation and thereby relegated to a secondary status, on the other. The relationship between leaders-who donate money to the religious cause - and specialists—who are paid, albeit in varying ways: salary, use of temple lands, right to fees and donations-is one of asymmetrical contractual employment in which the symbolic high ground is held by the lay leaders. The vocabulary of employment clearly expresses the subservient position of the paid specialist, even though s/he may try to redefine the payment as donation/gift. It is through giving one's time and money-to the point of self-sacrifice-that leadership and morality are linked.

For this reason, laypersons who take an active role in communal celebrations, such as leaders of lay congregations or lay musicians, ${ }^{10}$ pointedly decline to be paid as professional specialists, and act under the name of "community leaders." For instance, in parts of northern China, 
musicians observe a sharp distinction between professional outcasts (actors and hereditary musicians) organized in bands (ban, that is, the same vocabulary used by Daoist and Buddhist troupes) who suffer from a low reputation, and socially valued amateurs (organized in associations, hui) playing for festivals and funerals, who often are at the same time village elders or community leaders (and in communist China, village cadres). ${ }^{11}$ In this particular case, leaders also have an expertise (playing ritual music) but this expertise is a shared skill and not individual since everyone is welcome to learn and play.

\section{COMMUNITIES AGAINST SPEGIALISTS: THE AVOIDANCE OF CHARISMA}

For charismatic authority to exist in the classical sociological sense we need to have one person linking the idiom of self-cultivation (providing the extraordinary) with that of leadership, thus to generate a following, built either from scratch or from or within a pre-existing group. It seems that pre-existing groups, especially those based on the existing social order, such as ascriptive communities: territorial communities, lineages, corporations, are rarely susceptible to charismatic authority, at least under ordinary conditions, when their survival is not in question. The cases of "grassroots charisma" analyzed by Stephan Feuchtwang and Wang Mingming, who study contemporary leaders of local communities, might be understood as communities endangered by social and political change and that need charismatic leadership to reconnect past and future. This instance of charisma is squarely based on the leadershipmorality idiom, with lesser use of the self-cultivation and scholarship idioms, which may be described as closer to the political than the religious end of the spectrum of charismatic situations.

Certain communities rejected on principle any active role for religious professionals. An important reason behind such rejection was anticlericalism, that is, the rejection of religion as a profession and of clerical intermediaries in religious life. ${ }^{12}$ At the same time, many communities did work with religious specialists because they needed their expertise. Some scholars have tended to present Chinese communal religion as basically operating without religious specialists. ${ }^{13}$ When their financial and the political situation permit, however, most communities actually did and do choose to work with a variety of specialists, supporting large numbers of them in the cities, but they usually maintained a distance from them. This distance was most clearly expressed in the vocabulary and terms of address used to designate community members and leaders on the one hand, and religious specialists working for them, on the other. Religious specialists were typically addressed as experts (with terms such as -sheng, -shi), that express respect for technical knowledge but do not imply leadership. 
One particularly clear case of communities' (mostly, ascriptive communities) sidelining religious specialists is the question of temple management. $^{14}$ In late imperial times, the major clerical training institutions-e.g., Buddhist monasteries, Daoist central temples or monasteries, Confucian academies-were run by elite clerics, and religious lineages ( fapai, zongpai) owned important numbers of temples and hermitages. Many temples, however, were owned and run by lay communities, such as territorial communities, lineages, guilds, or congregations. Most of these temples did not have a resident specialist, but an important proportion did: over half in some of the richest cities. The historical record shows that communities employing a resident specialist often did not accord much importance to whether their manager was Buddhist or Daoist or something else, but focused on making sure s/he did not transgress the prerogatives and rights of the temple leaders, and was kept under control. To this end, temple management contracts were drawn up between the temple leaders and the employed clerics, describing in great detail their rights and duties, and making abundantly clear that the major decisions within the community were the prerogatives of the lay leaders, not the manager. Employed clerics were often not allowed to raise funds on their own initiative or to form their own congregations. In other words, they were denied the right to display the very ability on which charisma is grounded, such as raising money to rebuild a temple, or teaching their own congregation.

This general picture suggests a dominant logic in modern and contemporary Chinese society that separates the roles and symbolic repertoires of leaders/amateurs and experts/professionals. Existing communities can use the services of providers of the extraordinary. The historical and ethnographic records are full of cases of communities that hire a self-cultivation virtuoso for fundraising, or for performing a miracle in times of need-and that often then turn him or her into a protective god when dead. But it is much less common that they become their followers when alive. In other words, the standard situation in Chinese society seems to be one of avoidance of charismatic relationship, at least with a human being.

\section{AWE VERSUS CHARISMA}

In order to analyze this situation where leadership and religious competence are disjoined, I would like to introduce an opposition between awe and charisma. By awe, I mean the recognition that an individual has attained self-cultivation excellence and might, if asked, provide extraordinary happenings. Awe that is not harnessed into a charismatic relationship remains a feeling; it does not imply a bond; there is no promise made on either side. There is no following that consistently awaits the occurrence of the extraordinary; but people know or 
feel that, if necessary, the possibility is there. Wonder-workers, yiren, (lit. extraordinary persons), inspire awe, and are included in many if not most stories describing the origins of religious practices and lineages, but never as leaders. Eminent clerics ("high Daoists/Buddhists," gaodao, gaoseng) also inspire awe. People know that they could make things happen but, with the exception of a small number of disciples, they do not ask for it.

Let me provide an example from a 1903 inscription commemorating a Daoist from Beijing:

The Daoist Wang Junfeng's . . . complexion was red and his body fat, he had sparse hair and a thin mustache, and his eyes shone like lightning. By nature he was honest and hard-working. He liked to solve problems for people and arbitrated conflicts, practiced medicine and gave away drugs; he rejoiced when he saw virtuous actions and took wickedness as his own enemy. Such was his innate nature. With just a robe and two hair buns, he wandered freely and had the look of a divine immortal ... After Wang had obtained the secret oral instructions of alchemical training, he retreated [from society] to practice them ... There he refined himself in silence for several years until his body and soul were firmly fixed. In 1881, he came to the Mashen miao [a temple in the inner city]. At that time, the temple's halls were in ruin, having been neglected for years... Wang settled down between the dilapidated rooms and the crumbling wall. During the daytime, he went out and begged for his living, and he returned at night to meditate. He was pleased with his vegetarian fare and his miserable robe. Then our Daoist solemnly vowed to raise a subscription and restore the temple. With his disheveled hair and bare feet, he walked in the snow through the freezing cold of winter, or went around under the scorching heat of spring. He routinely endured pains that other people considered unbearable. But utmost sincerity moves people, and eventually the Beijing people came to look at him in awe. Their contributions added up like hairs woven into a cloth, and the temple was restored to its former splendor. But, although the temple was now like new, it ran the risk of falling again into ruins if nobody continued the task of managing it. Fortunately, several persons, notably Li, Yang and Jin, came one after the other to take Wang as their master, supported him generously, and thereby ensured that Wang's sustenance was guaranteed. ${ }^{15}$

All the classical elements of the self-cultivation idiom are assembled here: Wang has extraordinary physical features, and the ability to move people. A total stranger, he accomplishes the extraordinary feat of raising enough money to rebuild a temple. But instead of finding followers, he attracts three disciples who are described as successors in his lineage. The temple he builds does not spawn a separate community centered around him. Awe may surround eccentric ascetics like Wang, much as it may surround more exalted, institutional figures like the 
Zhang Heavenly Master who hereditarily presided over a Daoist clerical bureaucracy managing ordinations and exorcisms. ${ }^{16}$ The Heavenly Masters, a very particular instance of "office charisma" (Weber's amtscharisma), were followed by awed crowds wherever they went, yet besides taking on a few very wealthy merchants or officials as private disciples, they kept to their bureaucratic role and never built a personal following unlike what Pope John Paul II or other Christian institutional leaders achieved.

In such cases, it seems that we have persons with charismatic potential, a potential that is not actualized in a bond with followers and charismatic authority. By charismatic potential, I mean an excellence in the self-cultivation idiom and the mastery of bodily, oratorical, and other techniques indispensable to charismatic leaders. If charisma is an expectation of the extraordinary, then we can define charismatic potential as the ability (as estimated by outsiders, such as the social scientist) of a person to give rise to such an expectation, without promising to meet it. A number of contemporary Daoists David Palmer and I have observed exhibit this potential, for instance, by managing to put themselves at the center of any discussion, dictate questions and answers, draw on their own life experiences to make sense of any argument or topic being discussed, and thereby make themselves exemplary. In that sense, charismatic potential corresponds to charisma in the current cultural sense, as a trait of character or ability of a person, rather than charisma as defined by social scientists in terms of social relationships. ${ }^{17}$ For such charismatic potential to become charismatic authority, it needs somehow to be negotiated, put in place.

In most cases this does not happen. The reasons for such a failure, or avoidance, can be many. Some potential leaders may desire followers, but fail to find them. Clearly, others do not want to become charismatic leaders in the first place. We have seen that the normative role models of Daoists, Confucians, and Buddhists are at odds with charismatic ambitions. Another constraint is that the state, both imperial and under Communism, has always tried to prevent the emergence of charismatic authority. Actually, according to the Qing dynasty's (1644-1911) law, only ascriptive communities were legal, and congregations were banned, even if widely tolerated in actual fact. For this reason, many Buddhist and Daoist clerics found it safe to keep to the legally acceptable role of employee of an ascriptive community rather than creating congregations, which ran the small, but not negligible, risk of landing them in court. There certainly were explosions of charismatic movements at times when state control over charisma loosened, such as during the 1910-1930 period, and again since the 1980s, as can be seen both in the People's Republic of China with the proliferation of Qigong masters, and in Taiwan where new religious groups are now being founded as a dizzying pace. 


\section{MANUFACTURING A FOLLOWING}

For an individual who has cultivated charismatic potential and who wants to establish charismatic authority - that is, build a followingsome sort of negotiation with potential followers needs to take place. Lorne Dawson draws our attention to the observable behaviors by which potential leaders express their ambition to establish charismatic authority, and thereby seek followers. ${ }^{18}$ Among such behaviors observed among Chinese religious specialists, one seems peculiarly important: an expressed willingness to "save the world" ( jiushi, a keyword in most if not all Chinese charismatic movements), that is, not only produce extraordinary events for individuals, but to reach out and explicitly address the transformation of the community. It is one thing to heal a few people; it is quite another to promise to heal everyone.

For instance, one very successful spirit-medium I have observed in Hong Kong not only heals individuals, but also seeks occasions to address society at large on how to lead a good life and do good. He is thoroughly and spectacularly engaged in large charity programs, thereby establishing himself as a benefactor of society and a model of selflessness that followers admire and try to emulate. These followers have established well-structured organizations that go far beyond the clientele of this spirit-medium's patients. While his followers can not imitate his healing practice-because only he is possessed by the god-they do imitate his way of giving away and sharing around him, especially food. In contrast to other spirit-mediums who have founded successful client cults that I observed in Taiwan, the spirit-medium says he helps his followers because he loves them, not only because his possessing deity commands him to. In this instance, love is explicitly and visibly made a crucial part of the relationship. Followers say they volunteer to help him in his work because they love him, not merely because they have made a vow to do so if their prayers were answered. ${ }^{19}$

I suspect this is an enduring pattern: spirit-mediums are probably on aggregate the most numerous providers of the extraordinary in modern and contemporary Chinese society, but only a fraction of them take the leap and move from offering services to individuals, to focusing on communal salvation. The case of Zhengyan, the Buddhist nun who established the Tzu Chi foundation studied in this issue by Julia Huang, is also based on charity as the foundation for the transformation of the community, and as one person's practice of selflessness becoming a model for everyone, a communal charter.

Another behavior that promises charismatic authority is to willingly answer, and indeed invite any question be it practical or theoretical, provide advice on life-choices and thereby become a comprehensive source of meaning. This meaning need not be new, but the point is that it is newly accessible. Potential followers now have a single person they can 
easily go to and ask questions on anything: morality and retribution (explaining one's misfortunes); how to bring about blessings and change one's life here and now; how to make sense of what other moral authorities (for example, state agents, clerics, school teachers, science and tradition) say and solve the contradictions between them. Most religious specialists limit their field of expertise to one or another aspect of the demand for meaning.

The case of Li Yuansong, the founder of the Modern Chan Society studied by Ji Zhe in this issue, seems typical. Not only was $\mathrm{Li}$, as a selfproclaimed enlightened Buddhist, able to teach meditation to his students, but he also was able to build an entire self-sufficient system of thought and practice. Another obvious case is Li Hongzhi of Falun Gong who became a truly charismatic figure when he switched from teaching a technique to teaching an all-encompassing moral system. In doing so, both departed from the path espoused by most self-cultivation teachers who focus on spiritual training and refrain from elaborating on morality or ritual practice. When doing so, they must master at least the outside forms and idiom of scholarship-such as quoting from the classics, even if superficially - in order to speak with authority, while at the same time appearing as the opposite of specialized scholars, such as diviners. In other words, the charismatic offer is to abolish the division of religious labor so entrenched in modern Chinese society and to merge all roles and resources in one person-a tempting but daunting proposition, given the high level of competition between specialists. Charismatic authority, then, combines religious roles that are normally kept separate.

For the above reasons, I suspect that in order to be a viable charismatic leader, a Chinese religious specialist must not only be a provider of the extraordinary, but must also master the idiom of scholarship; be able to teach, talk about any subject, and rise up to the challenge of coherence. One important attraction of Yiguandao and other groups formed by charismatic leaders during the twentieth century is that they provide access to the "great tradition" of Chinese cosmology and thought. ${ }^{20}$ Spirit-mediums follow a similar path when they start to teach, comment on classics, and establish their own doctrine, teaching, or sect (men, lit. door, access, but also following, clientele, or descent group) ${ }^{21}$

\section{TYPES OF FOLLOWING}

Followings based on charismatic authority are not easily defined, and in contrast to well-structured religious communities based on the existing social order, they are more like a residual category rather than a well defined type. ${ }^{22}$ We can find them stretching along a wide spectrum. On one end of the spectrum, highly ephemeral and unstructured clienteles are not, properly speaking, a following, unless we want to 
stretch the definition of charisma exceedingly far. On the other end, well-structured communities (territorial communities, lineages) can intersect charismatic projects, but not coincide with them. Somewhere in the middle, we find congregations with some degree of named, visible identity, typically called in a Chinese context a hui or she. I would like to evoke here two ideal types of such followings: the client cults engineered by entrepreneurial Daoists, Buddhists, or spirit-mediums; and the self-cultivation congregations. Both types of groups were common in late imperial cities and still are, at least in Taiwan and Hong Kong.

The religious specialists who engineered client cults apparently often did so because, lacking access to temple employment, they had little other option to establish themselves. In pre-1949 China, and today in Taiwan and Hong Kong, many Buddhists or Daoists started by opening a small hall offering ritual services, commonly termed a "Buddha shop," (fodian or pusadian). Heavily criticized by officials and intellectuals for turning religion into a business, some Buddha shops were nonetheless quite successful, transforming some clients into disciples, and creating a following large enough to underwrite the establishment of a fullfledged temple. Similarly, some spirit-mediums started from a home altar and endeavored, as their clients grew more numerous, to eventually build their own temple. ${ }^{23}$ In many parts of China an important part of the associations that brought money to temples were organized and led by spirit-mediums. ${ }^{24}$ Even when they succeeded in building large institutions, however, such entrepreneurial specialists typically did not create a full-fledged community. As in client cults, client-specialist bonds do not easily translate into bonds between clients or into a common identity-with some exceptions, such as the Zhenfozong (True Buddha School) which, as Tam Wai-lun shows, started in the 1970s with many characteristics of a client cult run by an entrepreneurial spiritual master but soon evolved into a full-fledged religion. ${ }^{25}$ In client cults, charismatic potential is often not fully actualized, as members also turn to other leaders or religious specialists to provide alternative or complementary services and meaning.

By way of contrast, spiritual masters teaching self-cultivation techniques were often more successful at engineering real followings, lasting over time and identified not only by their relationship with the master but also by shared texts and practices. In the diverse self-cultivation milieu comprised of Buddhist, Daoist, and Confucian clerics, doctors, martial artists, members of spirit-writing cults and others, ${ }^{26}$ clerics were held in high esteem and considered as authorities but typically taught only within the framework of master-disciple lineages and took few disciples. However, some turned into charismatic leaders by setting up a distinct teaching (often but not necessarily based on a revelation, typically obtained through spirit-writing), a comprehensive system of practice, communal celebrations, scriptures, and ethical norms. Let me very 
briefly mention one example of a Confucian turned charismatic leader: Liu Yuan (1768-1855), a failed scholar set up his teaching complete with scriptures, a liturgy (basically Daoist), temples where he taught straightforward Confucian doctrine, a self-cultivation regimen (also basically Daoist), and an ethical code. ${ }^{27}$

There was a continuous stream of creation of such movements during the late imperial era, followed by an explosion in the early twentieth century, ${ }^{28}$ when they openly expanded and even dominated the religious landscape in some cities and regions. Several of them also founded national modern-style associations which registered with the state as religious, philanthropic, or public interest associations, with a head office, a national organization with provincial and municipal branches, and a doctrine which attempted to modernize the traditional notion of the union of the Three Teachings with the aid of a more modern, academic language and by incorporating Christianity and Islam into the traditional Union of the Three Teachings. The largest and most sophisticated of these redemptive societies ${ }^{29}$ included the Zailijiao (Teaching of the Abiding Principle), the Daode xueshe (Moral Studies Society); the Tongshanshe (Fellowship of Goodness); the Wanguo daodehui (Universal Morality Society); the Daoyuan (School of the Dao); and the Jiushi xinjiaohui (New Religion to Save the World). The redemptive societies often had their own scriptures, philosophical systems, liturgies (simplified from Confucian, Buddhist and Daoist sources), congregational modes of participation, and hierarchical national organizations.

The founders and leaders of the redemptive societies do not fit one single type, but all mastered the idioms of self-cultivation and scholarship, and offered to "save the world" by setting up charities, social organizations, and programs of collective practice, as well as putting forth, in book form, comprehensive doctrinal formulations. The example of $\mathrm{Li}$ Yujie, studied by David Palmer, ${ }^{30}$ is illuminating. Li practiced meditation with Daoists on a sacred site, and wrote about his accomplishments; he also worked as a scholar, and as a social activist as well as businessman, all before eventually creating his own redemptive society.

More than the contents of the practice and teaching, it thus seems that redemptive societies distinguish themselves by the mode of authority at work. I would suggest that the various types of self-cultivation practice in modern and contemporary China can be divided into four broad, ideal-typical types, with many groups evolving from one type to another over time, without changing the techniques taught. The first type is the pure master-disciple relationship within a lineage, as practiced in Daoist and Buddhist clerical circles. Type 2 is the closed group of adepts forming a brotherhood, not necessarily with a (living) master, as often seen in spirit-writing groups. Type 3 is a larger, looser network or community of practitioners exchanging help and advice, often through written 
media (journals, books) and occasionally meeting with a master, as developed by Daoist masters such as Zhao Bichen (1860-1942) ${ }^{31}$ or Chen Yingning (1880-1969), ${ }^{32}$ or later Qigong movements. ${ }^{33}$ Finally, the fourth type is a religious group practicing a self-cultivation method (gongfa) within the framework of a larger moralistic discourse, such as in the redemptive societies or the Falun Gong.

Lee Fong-mao's research on self-cultivation groups in Taiwan after 1950 shows how the role of spiritual masters varies between these different types of groups. ${ }^{34} \mathrm{He}$ observes groups that remain within the clerical lineage model (type 1) competing with ascetic groups offering training classes (types 2 and 3), and redemptive societies (type 4) where self-cultivation is merely one element in a larger religious practice. All of these groups make claims of authority by using Daoist self-cultivation resources, such as texts, images, charismatic authority of past patriarchs, and lineage legitimacy. Many masters leading these various groups claim an initiation from a Daoist-directly or at earlier stages of their lineage history - to legitimize themselves, and such claims were also common in the Qigong movement. However, the status of these masters differs widely according to the type of group they teach to. In type 1 , they are or act like Daoists as far as their self-representation and social role are concerned, combining the self-cultivation and scholarship idioms. By contrast, they tend to adopt a very different social role, that of a scholar (with doctrinal or intellectual authority, based on published writings and formal classroom teaching) in type 2 and 3 , and of a congregational leader exerting charismatic authority in type 4 .

\section{CONGLUSION}

The success stories of modern Chinese charismatic leaders all seem to be cases of joining into one person the different idioms of self-cultivation, scholarship, and leadership. Persons who have been trained into, and manage to behave according to these different idioms, performing individual extraordinary events, but embodying self-sacrifice for the community, often attract a following. When they find it, charismatic authority is established. Charisma, then is willed by both parties in the relationship, hence a possible elaboration on our working definition: charisma then would be a "negotiated expectation of the extraordinary," that is, a negotiation has taken place whereby the provider of the extraordinary agrees to make him/herself and his/her capacity to make things happen fully and continually available to one following; and the followers agree to refer all their religious needs to this provider. In many cases, charismatic potential exists, but is not actualized, because either the person having nurtured this potential or the prospective followers are not interested, and/or because of legal and social constraints against charismatic authority. 


\section{ENDNOTES}

${ }^{1}$ On historical change, see David Palmer and Vincent Goossaert, The Religious Question in Modern China (manuscript in progress).

${ }^{2}$ Brigitte Baptandier, "Façonner la divinité en soi: À la recherche d'un lieu d'énonciation" ("Constructing One's Own Divinity: The Search for a Place from which to Speak”) Ethnologies 25, no. 1 (2003): 109-51.

${ }^{3}$ Vincent Goossaert, "Starved of Resources: Clerical Hunger and Enclosures in Nineteenth-Century China," Harvard Journal of Asiatic Studies 62, no. 1 (2002): $77-133$.

${ }^{4}$ Vincent Goossaert, “Abbés et saints crasseux: Essai de définition des autorités religieuses en Chine (1400-1911)" (Abbots and Filthy Monks: Defining Religious Authority in China [1400-1911]), in Les autorités religieuses (Religious Authorities), ed. Denise Aigle (Turnhout: Brepols, forthcoming).

${ }^{5}$ Jean DeBernardi, The Way that Lives in the Heart: Chinese Popular Religion and Spirit Mediums in Penang, Malaysia (Stanford: Stanford University Press, 2006).

${ }^{6}$ DeBernardi, The Way that Lives in the Heart, Chapter Six, notes that when spiritmediums begin to teach, they are called xiansheng.

${ }^{7}$ For the training and habitus of a Confucian scholar, see Henrietta Harrison, The Man Awakened from Dreams: One Man's Life in a North China Village, 1857-1942 (Stanford: Stanford University Press, 2005); for Daoists, see Kristofer Schipper, The Taoist Body (Berkeley: University of California Press, 1993).

${ }^{8}$ Schipper, The Taoist Body.

${ }^{9}$ Vincent Goossaert, The Taoists of Peking, 1800-1949. A Social History of Urban Clerics (Cambridge, Mass.: Harvard University Asia Center, 2007), 284-85.

${ }^{10}$ For instance, Thomas D. Dubois, The Sacred Village: Social Change and Religious Life in Rural North China (Honolulu: University of Hawai'i Press, 2005).

${ }^{11}$ See notably Stephen Jones, Plucking the Winds_Lives of Village Musicians in Old and New China (Leiden: CHIME, 2004).

${ }^{12}$ On anticlericalism, see Vincent Goossaert, ed., Anticléricalisme en Chine (Anticlericalism in China), special issue of Extrême-Orient Extrême-Occident 24 (2002).

${ }^{13}$ For a recent, strong formulation of this thesis, see Daniel L. Overmyer, "Ritual Leaders in North China Communities in the Twentieth Century: A Report on Research in Progress," Min-su ch'ü-yi 153, special issue on Religious Specialists and Local Communities (September 2006): 203-63.

14 Vincent Goossaert, "Resident Specialists and Temple Managers in Late Imperial China," Min-su ch'ü-yi 153, special issue on Religious Specialists and Local Communities (September 2006): 25-68.

15 Goossaert, Taoists of Peking, 131-33.

16 Vincent Goossaert, "Bureaucratic Charisma: The Zhang Heavenly Master Institution and Court Taoists in late-Qing China," Asia Major 3rd series, 17, no. 2 (2004): 121-59.

17 Stephen Turner, “Charisma Reconsidered," Journal of Classical Sociology 3, no. 1 (2003): 5-26.

${ }^{18}$ Lorne L. Dawson, "Psychopathologies and the Attribution of Charisma," Nova Religio: The Journal of Alternative and Emergent Religions 10, no. 2 (2006): 3-28. 


\section{Nova Religio}

${ }^{19}$ Dawson, "Psychopathologies" draws attention to love as a crucial element of charisma.

${ }^{20}$ David Jordan and Daniel L. Overmyer, The Flying Phoenix. Aspects of Chinese Sectarianism in Taiwan (Princeton, N.J.: Princeton University Press, 1986).

${ }^{21}$ DeBernardi, The Way that Lives in the Heart, Chapter Five.

22 Turner, "Charisma Reconsidered."

${ }^{23}$ Chao Shin-yi, "A Danggi Temple in Taipei: Spirit-Mediums in Modern Urban Taiwan,” Asia Major 3rd series, 15, no. 2 (2002): 129-56.

${ }^{24}$ Li Wei-tsu, "On the Cult of the Four Sacred Animals (Szu Ta Men) in the Neighborhood of Peking," Folklore Studies 7 (1948): 1-94 for the case of Beijing. 25 TAM Wai Lun, "Integration of the Magical and Cultivational Discourses. A Study on a New Religious Movement Called the True Buddha School," Monumenta Serica 49 (2001): 141-69.

${ }^{26}$ Vincent Goossaert, "Taoists in the Modern Self-cultivation Market: the Case of Peking, 1850-1949," in Taoism in the Twentieth Century: Between Eternity and Modernity, ed. David Palmer and LIU Xun (Berkeley and Los Angeles: University of California Press, 2009).

${ }^{27}$ MA Xisha and Han Bingfang, Zhongguo minjian zongiiao shi (The History of Chinese Popular Religion) (Beijing: Zhongguo shehui kexue chubanshe, 2004), 1006-33.

${ }^{28}$ Palmer and Goossaert, The Religious Question in Modern China, Chapter 4.

${ }^{29}$ Prasenjit Duara, Sovereignty and Authenticity: Manchukuo and the East Asian Modern (Lanham, Md.: Rowman \& Littlefield, 2003), 103-22.

${ }^{30}$ David Palmer, "Tao and Nation: Li Yujie and His Appropriation of Huashan Taoism," in Palmer and Liu, Taoism in the Twentieth Century.

${ }^{31}$ Goossaert, Taoists of Peking, 297-306.

${ }^{32}$ LiU Xun, Daoist Modern: Chen Yingning and Daoist Inner Alchemic Practice in Republican Shanghai (Cambridge, Mass.: Harvard University Asia Center, forthcoming).

${ }^{33}$ David Palmer, Qigong Fever: Body, Science and Utopia in China (New York: Columbia University Press, 2007).

${ }^{34}$ LEE Fong-mao, "Transmission and Innovation: The Modernization of Elixir Taoism in Post-War Taiwan," in Palmer and Liu, Taoism in the Twentieth Century; see also Li Shiwei, "Jieyan qian Taiwan xiandao tuanti de jieshe yu huodong, 1950-1987" ("The Formation and Activities of the Immortality Societies in Taiwan before the Lifting of Martial Law, 1950-1987") in Xianggang ji Huanan daojiao yanjiu (Research on Daoism in Hong Kong and South China), ed. LAI Chi-tim (Hong Kong: Zhonghua shuju, 2005), 485-514. 